\title{
Persistent delirium in older hospital patients: an updated systematic review and meta-analysis
}

Jonathan Whitby ${ }^{1}$, Anita Nitchingham ${ }^{2,3}$, Gideon Caplan ${ }^{2,3}$, Daniel Davis ${ }^{1}$, Alex Tsui $^{1}$

1. MRC Unit for Lifelong Health and Ageing at UCL, London, UK

2. The Prince of Wales Clinical School, University of New South Wales, Sydney, Australia.

3. Department of Aged Care, Prince of Wales Hospital, Sydney, Australia.

\section{Address for correspondence:}

Alex Tsui

MRC Unit for Lifelong Health and Ageing at UCL

1-19 Torrington Place

London, WC1 7HB,

UK

a.tsui@ucl.ac.uk 


\begin{abstract}
Introduction

Persistent delirium is recognised as a substantial problem, but there are few insights into which patient groups might be particularly affected. Delirium is associated with future dementia progression. Yet whether this occurs subclinically over months and years, or persistent delirium merges into worsened dementia is not understood.
\end{abstract}

\title{
Methods
}

We adopted an identical approach to a previous systematic review, only including studies using a recognised diagnostic framework for ascertaining delirium at follow-up (persistent delirium). We applied risk of bias assessments based on Standards of Reporting of Neurological Disorders criteria. Estimates were pooled across studies using random-effects meta-analysis, and we estimated associations with age and follow-up duration using metaregression.

\section{Results}

We identified 13 new cohorts, which we added to 8 from the previous systematic review (21 relevant studies reporting persistent delirium over 37 time points). Studies were mainly at low risk of bias. Pooled delirium prevalence estimates at discharge were $40 \%$ (95\% Cl $24 \%$ to $54 \%, 10$ studies). Meta-regression showed variation in prevalence of persistent delirium over time ( $0.6 \%$ per week, $95 \% \mathrm{Cl}-1.2$ to $-0.1, \mathrm{p}=0.02)$. Older study sample age was associated with higher prevalence of persistent delirium (8.8\% per SD age, $95 \% \mathrm{Cl} 1.1 \%$ to $17 \%)$. The rate of improvement was the same regardless of age, but the overall burden was higher with older age such that $44 \%(95 \% \mathrm{Cl} 11 \%$ to $76 \%)$ of 95 -year-olds would be expected to have persistent delirium at 12 months.

\section{Conclusions}

This systematic review emphasises the key importance of delirium as a persistent and extensive problem, particularly in the oldest-old. Addressing persistent delirium will require a whole-system, integrated approach in order to detect, follow-up and implement opportunities for recovery across all healthcare settings. 


\section{Introduction}

Delirium is widely recognised as having a substantial impact on healthcare for older people, with several clinical guidelines serving to address its detection, prevention and management in hospitals. ${ }^{4,5}$ However, many questions remain over the natural history of delirium, particularly its relationship with dementia. ${ }^{6}$ For example, it is not clear if underlying dementia leads to a more severe or prolonged delirium. ${ }^{7}$ We know that delirium is associated with future dementia progression. ${ }^{1-3}$ Yet whether this occurs subclinically over months and years, or persistent delirium merges into worsened dementia is not understood.

Persistent delirium has been of interest since a systematic review from 2009 suggested one in five cases were still evident six months after discharge. ${ }^{8}$ Subsequently, the number of older people presenting for urgent and emergency care has increased. ${ }^{9}$ There has also been a consistent trend for more acute presentations of people living with dementia; around half are admitted within the first 12 months of diagnosis. ${ }^{10}$ In light of these changes, we set out to update the systematic review to provide current estimates for the epidemiology of persistent delirium.

\section{Methods}

\section{Eligibility criteria}

We followed the 2020 PRISMA guidance. ${ }^{11}$ We used the same criteria applied in the previous systematic review: (i) study population of at least 20 hospital patients; (ii) patients aged $\geq 50$ years; (iii) prospective study with follow-up of at least one week; (iv) acceptable definition of delirium at enrolment. We excluded studies investigating delirium in critical care and in the context of terminal illness or palliative care. Our only modification was to require studies to use a recognised diagnostic framework for ascertaining delirium at follow-up (persistent delirium); studies from the original systematic review meeting this criterion were carried over into the current analysis. Given this was an update of a previous systematic review, we did not devise a de novo protocol for PROSPERO.

\section{Outcome measures}

The primary outcome was proportion of patients with delirium at follow-up, where the denominator was the number of participants who had delirium at inception. We considered any definition based on the Diagnostic and Statistical Manual (DSM), International Classification of Disease, the Confusion Assessment Method (CAM) or the Delirium Index to be sufficiently detailed to ascertain delirium reliably. 


\section{Search strategy}

Updating the original review, we searched from 1 year before the previous end date (September 2006) to $11^{\text {th }}$ January 2022. We searched the same electronic databases: MEDLINE, EMBASE, PsycINFO and the Cochrane Database of Systematic Reviews, using the following search terms: Delirium [Title] AND (prognosis OR outcome OR aged OR occurrence) [Title/Abstract], replicating the original search strategy. We confirmed the sensitivity of the search by ensuring that we captured all studies from the previous review.

\section{Data collection and study selection}

Covidence (www.covidence.org, Veritas Health Innovation Ltd.) was used to manage the abstract and full-text screening, assessing risk of bias and data extraction. Three researchers independently reviewed titles and abstracts (J.W., A.N., A.T.) to determine the eligibility. Conflicts were resolved by discussion and consensus. The same reviewers extracted data using a pro forma.

\section{Assessment of quality and biases}

We determined risk of bias based on the framework outlined by the Standards of Reporting of Neurological Disorders (STROND) criteria. ${ }^{12,13}$ We considered bias arising (i) from specific patient settings, e.g., general medical patients, cohort with intracerebral haemorrhage; (ii) from sample selection, e.g., convenience, consecutive; (iii) from sample criteria, e.g., excluding patients unable to consent, assessed as being too sick; (iv) from reference standard used, e.g., DSM, CAM; (v) from expertise in applying the reference standard, e.g. routine data, dedicated researcher. We rated studies high, low or unclear risk of bias in each of the five domains. Quality of evidence was assessed using the GRADE framework, which considers risk of bias, inconsistency, indirectness, imprecision and publication bias.

\section{Statistical analysis}

We extracted summary statistics for the prevalence of persistent delirium at each time point and calculated their standard errors (sqrt $[p(1-p) / n)]$. We assumed methodological heterogeneity across studies, accounting for this using DerSimonian-Laird random-effects models. ${ }^{14}$ Statistical heterogeneity was assessed with the $\mathrm{I}^{2}$ statistic. Meta-regression was used to estimate the relationship between persistent delirium and follow-up time, mean age, and dementia prevalence in each study sample. We plotted marginal predictions for any parameter associated with persistent delirium. To assess publication bias, we plotted the estimated proportion of delirium occurrence against the standard error of that estimate and 
medRxiv preprint doi: https://doi.org/10.1101/2022.01.20.22269044; this version posted January 21, 2022. The copyright holder for this preprint (which was not certified by peer review) is the author/funder, who has granted medRxiv a license to display the preprint in perpetuity.

It is made available under a CC-BY 4.0 International license.

inspecting the degree of asymmetry. We used Stata 16.1 (StataCorp, Texas) for all analyses.

\section{Results}

We identified 6474 articles, screening 5556 after removal of duplicates (see PRISMA diagram). We assessed 115 full-text articles for eligibility. We identified 13 new cohorts, which we added to eight from the previous systematic review, giving a total of 21 relevant studies reporting persistent delirium over 37 time points (Table 1). ${ }^{15-34}$ Most studies were in medical patients and they were all from high-income settings and casemix by ethnicity was not generally reported. Samples ranged in size $(n=23$ to $n=278)$ and duration of follow-up (up to 12 months). Average age and proportion with dementia were reported as 82.3 years and $43 \%$ respectively, though both varied substantially between different study cohorts.

In the main, studies were at low risk of bias insofar as most followed a sample representative of the target setting (e.g., acute hospital care) and used consistent outcome ascertainment instruments (GRADE certainty rating for risk of bias = 'low') (Figure 2). Around half excluded patients unable to give consent (and did not report procedures to allow proxy consent) and/or excluded participants too sick to assess for delirium. Case ascertainment was based on a consensus definition (e.g. DSM) in 6 studies; the rest used instruments such as CAM. Given each has different degrees of restrictiveness in their definition, ${ }^{35}$ the GRADE certainty rating for indirectness was 'moderate'.

Pooled delirium prevalence estimates at discharge were 40\% (95\% Cl 24\% to 54\%, 10 studies) (Figure 4). Although there were few studies with data beyond 6 months, each time point reported considerable persistent cases (pooled estimates ranging from $20 \%$ to $59 \%$ ). There was substantial statistical heterogeneity at all time points (all subgroup $\mathrm{I}^{2}>89 \%$ ) (GRADE certainty rating for imprecision = moderate). Funnel plots of prevalence versus the standard error of the estimate did not demonstrate any asymmetry, leading to a GRADE certainty rating for publication bias of 'high'.

Meta-regression showed variation in prevalence of persistent delirium over time $(0.6 \%$ per week, $95 \% \mathrm{Cl}-1.2$ to $-0.1, \mathrm{p}=0.02$ ) (Table 2). This monotonic decrease in prevalence over time led to a GRADE certainty rating for inconsistency as 'low'. Older study sample age was associated with higher prevalence of persistent delirium (8.8\% per SD age, $95 \% \mathrm{Cl} 1.1 \%$ to $17 \%$ ). Persistent delirium did not vary with the proportion of study sample with dementia, though only 14 studies reported this. Figure 4 shows the predicted meta-regression margins 
medRxiv preprint doi: https://doi.org/10.1101/2022.01.20.22269044; this version posted January 21, 2022. The copyright holder for this preprint (which was not certified by peer review) is the author/funder, who has granted medRxiv a license to display the preprint in perpetuity.

It is made available under a CC-BY 4.0 International license .

for three age groups over time. The rate of improvement was the same regardless of age, but the overall burden was higher with older age such that $44 \%$ (95\% Cl $11 \%$ to $76 \%)$ of 95 year-olds would be expected to have persistent delirium at 12 months. The overall GRADE certainty for this estimate is 'moderate'.

\section{Discussion}

We showed that persistent delirium remains a substantial problem well beyond the acute phase. This persistence does not appear to vary with baseline dementia, albeit using a study-level ecological measure of dementia. A clearer association was evident with increasing age. Taken together, these findings suggest a considerable need to focus delirium recovery for both individuals and health services.

Our data should be considered in light of a number of limitations. Other than duration, the variables we could use for meta-regression relied on study-level data on mean sample age and dementia prevalence. This limits the interpretation due to residual confounding for quantities such as frailty. Most studies had significant attrition due to mortality and loss to follow up, though this might be expected to underestimate the true prevalence of persistent delirium. All studies were performed in high-income countries, making it difficult to generalise our findings to other settings. Many studies only included delirium detected in the first 24-48 hours of admission, which could have led to under-ascertainment. There is likely to be a degree of overlap between the reports of delirium at discharge and some of the earlier follow-up time points (2-weeks and 4-weeks) because the former category encompassed a variable duration. Some publications only reported persistent delirium at discharge, so it is impossible to know how long these patients remained as cases. Similarly, it is unclear how long delirium might have been present prior to transfer for individuals admitted to post-acute care. We also restricted our search to studies published in English. Finally, we detected significant heterogeneity between studies, though we attempted to limit this by defining our outcome measure as precisely as possible.

In updating the original systematic review with 15 years' worth of new studies, we have extended those findings to demonstrate the highest prevalence of persistent delirium with older age. While older age is likely to be a proxy for dementia and frailty, the gradient suggests that delirium may never resolve in the oldest-old. More broadly, these data are consistent with terminal decline in cognition observed longitudinal studies. ${ }^{36}$ Higher education is associated with delayed onset, though a faster trajectory once terminal decline begins. ${ }^{37}$ Though previous cohorts have not considered delirium to be a driver, the Delirium 
medRxiv preprint doi: https://doi.org/10.1101/2022.01.20.22269044; this version posted January 21, 2022. The copyright holder for this preprint (which was not certified by peer review) is the author/funder, who has granted medRxiv a license to display the preprint in perpetuity.

It is made available under a CC-BY 4.0 International license .

and Population Health Informatics Cohort has that shown the largest post-delirium decline in cognition occurs in those with higher baseline cognition. ${ }^{38}$ Dedicated prospective studies are needed to fully capture the influence of evolving dementia reciprocally affecting persistent delirium.

The clinical implications of our findings indicate an urgent need to develop delirium recovery and cognitive rehabilitation services. These are almost non-existent, certainly out of proportion with the potential demand, though multicomponent interventions show promise. ${ }^{39}$ Recognising the opportunities for the emerging field of interface acute geriatrics would be an important starting point, ${ }^{40}$ and continued community-based management of delirium is likely to have an impact. ${ }^{41}$

This systematic review emphasises the key importance of delirium as a persistent and extensive problem, particularly in the oldest-old. Addressing persistent delirium will require a whole-system, integrated approach in order to detect, follow-up and implement opportunities for recovery across all healthcare settings.

\section{Acknowledgements}

JW is funded through a grant from the Dunhill Medical Association, DD is funded by the Wellcome Trust (WT107467). AT is an Alzheimer's Society Clinical Research Training Fellow. The MRC Unit for Lifelong Health and Ageing at UCL received core funding through the Medical Research Council (MC_UU_00019/1).

\section{References}

1. Davis DH, Muniz Terrera G, Keage H, et al. Delirium is a strong risk factor for dementia in the oldest-old: a population-based cohort study. Brain. Sep 2012;135(Pt 9):2809-16. doi:10.1093/brain/aws190

2. Gross AL, Jones RN, Habtemariam DA, et al. Delirium and Long-term Cognitive Trajectory Among Persons With Dementia. Arch Intern Med. Sep 24 2012;172(17):1324-31. doi:10.1001/archinternmed.2012.3203

3. Richardson SJ, Davis DHJ, Stephan BCM, et al. Recurrent delirium over 12 months predicts dementia: results of the Delirium and Cognitive Impact in Dementia (DECIDE) study. Age Ageing. Dec 16 2020;doi:10.1093/ageing/afaa244

4. Davis D, Searle SD, Tsui A. The Scottish Intercollegiate Guidelines Network: risk reduction and management of delirium. Age Ageing. Jul 1 2019;48(4):485-488. doi:10.1093/ageing/afz036

5. Wilson JE, Mart MF, Cunningham C, et al. Delirium. Nat Rev Dis Primers. Nov 12 2020;6(1):90. doi:10.1038/s41572-020-00223-4 
medRxiv preprint doi: https://doi.org/10.1101/2022.01.20.22269044; this version posted January 21 , 2022. The copyright holder for this preprint (which was not certified by peer review) is the author/funder, who has granted medRxiv a license to display the preprint in perpetuity.

It is made available under a CC-BY 4.0 International license.

6. Davis DH, Kreisel SH, Muniz Terrera G, et al. The epidemiology of delirium: challenges and opportunities for population studies. Am J Geriatr Psychiatry. Dec 2013;21(12):1173-89. doi:10.1016/j.jagp.2013.04.007

7. Morandi A, Bellelli G. Delirium superimposed on dementia. Eur Geriatr Med. Feb 2020;11(1):53-62. doi:10.1007/s41999-019-00261-6

8. Cole MG, Ciampi A, Belzile E, Zhong L. Persistent delirium in older hospital patients: a systematic review of frequency and prognosis. Age Ageing. Jan 2009;38(1):19-26. doi:10.1093/ageing/afn253

9. Gruneir A, Silver MJ, Rochon PA. Emergency department use by older adults: a literature review on trends, appropriateness, and consequences of unmet health care needs. Med Care Res Rev. Apr 2011;68(2):131-55. doi:10.1177/1077558710379422

10. Sommerlad A, Perera G, Mueller C, et al. Hospitalisation of people with dementia: evidence from English electronic health records from 2008 to 2016. Eur J Epidemiol. Jun 2019;34(6):567-577. doi:10.1007/s10654-019-00481-x

11. Page MJ, McKenzie JE, Bossuyt PM, et al. The PRISMA 2020 statement: an updated guideline for reporting systematic reviews. Syst Rev. Mar 29 2021;10(1):89. doi:10.1186/s13643-021-01626-4

12. Bennett DA, Brayne C, Feigin VL, et al. Explanation and Elaboration of the Standards of Reporting of Neurological Disorders Checklist: A Guideline for the Reporting of Incidence and Prevalence Studies in Neuroepidemiology. Neuroepidemiology. 2015;45(2):113-37. doi:10.1159/000439132

13. Bennett DA, Brayne C, Feigin VL, et al. Development of the Standards of Reporting of Neurological Disorders (STROND) checklist: A guideline for the reporting of incidence and prevalence studies in neuroepidemiology. Neurology. Sep 1 2015;85(9):821-8. doi:10.1212/wnl.0000000000001866

14. DerSimonian R, Laird N. Meta-analysis in clinical trials. Control Clin Trials. Sep 1986;7(3):177-88. doi:10.1016/0197-2456(86)90046-2

15. Levkoff SE, Evans DA, Liptzin B, et al. Delirium. The occurrence and persistence of symptoms among elderly hospitalized patients. Arch Intern Med. Feb 1992;152(2):334-40. doi:10.1001/archinte.152.2.334

16. Rudberg MA, Pompei P, Foreman MD, Ross RE, Cassel CK. The natural history of delirium in older hospitalized patients: a syndrome of heterogeneity. Age Ageing. May 1997;26(3):169-74. doi:10.1093/ageing/26.3.169

17. Marcantonio ER, Flacker JM, Michaels M, Resnick NM. Delirium is independently associated with poor functional recovery after hip fracture. J Am Geriatr Soc. Jun 2000;48(6):618-24. doi:10.1111/j.1532-5415.2000.tb04718.x

18. McCusker J, Cole M, Dendukuri N, Han L, Belzile E. The course of delirium in older medical inpatients: a prospective study. J Gen Intern Med. Sep 2003;18(9):696-704. doi:10.1046/j.1525-1497.2003.20602.x

19. Kiely DK, Bergmann MA, Jones RN, Murphy KM, Orav EJ, Marcantonio ER. Characteristics associated with delirium persistence among newly admitted post-acute facility patients. J Gerontol A Biol Sci Med Sci. Apr 2004;59(4):344-9.

doi:10.1093/gerona/59.4.m344

20. McAvay GJ, Van Ness PH, Bogardus ST, Jr., et al. Older adults discharged from the hospital with delirium: 1-year outcomes. J Am Geriatr Soc. Aug 2006;54(8):1245-50.

doi:10.1111/j.1532-5415.2006.00815.x

21. Inouye SK, Zhang Y, Jones RN, Kiely DK, Yang F, Marcantonio ER. Risk factors for delirium at discharge: development and validation of a predictive model. Arch Intern Med. Jul 9 2007;167(13):1406-13. doi:10.1001/archinte.167.13.1406

22. Lundström M, Olofsson B, Stenvall M, et al. Postoperative delirium in old patients with femoral neck fracture: a randomized intervention study. Aging Clin Exp Res. Jun 2007;19(3):178-86. doi:10.1007/bf03324687

23. Kiely DK, Marcantonio ER, Inouye SK, et al. Persistent delirium predicts greater mortality. J Am Geriatr Soc. Jan 2009;57(1):55-61. doi:10.1111/j.1532-5415.2008.02092.x 
medRxiv preprint doi: https://doi.org/10.1101/2022.01.20.22269044; this version posted January 21 , 2022. The copyright holder for this preprint (which was not certified by peer review) is the author/funder, who has granted medRxiv a license to display the preprint in perpetuity.

It is made available under a CC-BY 4.0 International license

24. McManus J, Pathansali $\mathrm{R}$, Hassan $\mathrm{H}$, et al. The course of delirium in acute stroke. Age Ageing. Jul 2009;38(4):385-9. doi:10.1093/ageing/afp038

25. Arinzon Z, Peisakh A, Schrire S, Berner YN. Delirium in long-term care setting: indicator to severe morbidity. Arch Gerontol Geriatr. May-Jun 2011;52(3):270-5. doi:10.1016/j.archger.2010.04.012

26. Lee KH, Ha YC, Lee YK, Kang H, Koo KH. Frequency, risk factors, and prognosis of prolonged delirium in elderly patients after hip fracture surgery. Clin Orthop Relat Res. Sep 2011;469(9):2612-20. doi:10.1007/s11999-011-1806-1

27. Velilla NM, Bouzon CA, Contin KC, Beroiz BI, Herrero AC, Renedo JA. Different functional outcomes in patients with delirium and subsyndromal delirium one month after hospital discharge. Dement Geriatr Cogn Disord. 2012;34(5-6):332-6.

doi:10.1159/000345609

28. Witlox J, Slor CJ, Jansen RW, et al. The neuropsychological sequelae of delirium in elderly patients with hip fracture three months after hospital discharge. Int Psychogeriatr. Sep 2013;25(9):1521-31. doi:10.1017/s1041610213000574

29. Cole MG, Bailey R, Bonnycastle M, et al. Partial and No Recovery from Delirium in Older Hospitalized Adults: Frequency and Baseline Risk Factors. J Am Geriatr Soc. Nov 2015;63(11):2340-8. doi:10.1111/jgs.13791

30. Jackson TA, MacLullich AM, Gladman JR, Lord JM, Sheehan B. Undiagnosed longterm cognitive impairment in acutely hospitalised older medical patients with delirium: a prospective cohort study. Age Ageing. Jul 2016;45(4):493-9. doi:10.1093/ageing/afw064 31. Miu DK, Chan CW, Kok C. Delirium among elderly patients admitted to a post-acute care facility and 3-months outcome. Geriatr Gerontol Int. May 2016;16(5):586-92.

doi:10.1111/ggi.12521

32. Vasunilashorn SM, Marcantonio ER, Gou Y, et al. Quantifying the Severity of a Delirium Episode Throughout Hospitalization: the Combined Importance of Intensity and Duration. J Gen Intern Med. Oct 2016;31(10):1164-71. doi:10.1007/s11606-016-3671-9 33. Cole MG, McCusker J, Bailey R, et al. Partial and no recovery from delirium after hospital discharge predict increased adverse events. Age Ageing. Jan 8 2017;46(1):90-95. doi:10.1093/ageing/afw153

34. Reznik ME, Margolis SA, Mahta A, et al. Impact of Delirium on Outcomes After Intracerebral Hemorrhage. Stroke. Oct 5 2021:Strokeaha120034023.

doi:10.1161/strokeaha.120.034023

35. Gibb K, Seeley A, Quinn T, et al. The consistent burden in published estimates of delirium occurrence in medical inpatients over four decades: a systematic review and metaanalysis study. Age Ageing. Apr 27 2020;49(3):352-360. doi:10.1093/ageing/afaa040 36. Muniz-Terrera G, Matthews FE, Stephan B, Brayne C, Group CCC. Are terminal decline and its potential indicators detectable in population studies of the oldest old? Int $J$ Geriatr Psychiatry. Jun 2011;26(6):584-92. doi:10.1002/gps.2566

37. Terrera GM, Minett T, Brayne C, Matthews FE. Education associated with a delayed onset of terminal decline. Age Ageing. Jan 2014;43(1):26-31. doi:10.1093/ageing/aft150

38. Tsui A, Searle SD, Bowden $\mathrm{H}$, et al. The impact of baseline cognition and delirium on long-term cognitive impairment and mortality: a prospective population-based study. Lancet Healthy Longevity. 07/03/2022 2022;3(3)

39. O'Rourke G, Parker D, Anderson R, Morgan-Trimmer S, Allan L. Interventions to support recovery following an episode of delirium: A realist synthesis. Aging Ment Health. Oct 2021;25(10):1769-1785. doi:10.1080/13607863.2020.1793902

40. Rahman S, Byatt K. Follow-up services for delirium after COVID-19-where now? Age Ageing. May 5 2021;50(3):601-604. doi:10.1093/ageing/afab014

41. Caplan GA, Coconis J, Board N, Sayers A, Woods J. Does home treatment affect delirium? A randomised controlled trial of rehabilitation of elderly and care at home or usual treatment (The REACH-OUT trial). Age Ageing. Jan 2006;35(1):53-60.

doi:10.1093/ageing/afi206 
Table 1. Characteristics of included studies.

\begin{tabular}{|c|c|c|c|c|c|c|c|c|c|c|c|}
\hline Study & Setting & $\mathbf{N}$ & $\begin{array}{c}\text { Age } \\
\text { (years) }\end{array}$ & $\begin{array}{c}\text { Dementia } \\
(\%)\end{array}$ & $\begin{array}{c}\text { Delirium } \\
\text { ascertainment }\end{array}$ & Discharge & 2 weeks & 1 month & 3 months & 6 months & 12 months \\
\hline Levkoff 1992 & M, S & 91 & 81 & & DSM-III & $58 \%$ & & & $37 \%$ & $31 \%$ & \\
\hline $\begin{array}{l}\text { Rudberg } 1997 \\
\text { Marcantonio }\end{array}$ & M, S & 64 & 75 & 33 & DSM-III-R & $11 \%$ & & & & & \\
\hline 2000 & $S$ & 52 & 79 & 66 & CAM & $38 \%$ & & $29 \%$ & & $6 \%$ & \\
\hline Kelly 2001 & $M$ & 61 & 89 & & CAM & $72 \%$ & & $46 \%$ & $25 \%$ & & \\
\hline McCusker 2003 & M & 181 & 83 & 70 & $\mathrm{DI}$ & $32 \%$ & & & & $32 \%$ & $41 \%$ \\
\hline Kiely 2004 & PAC & 85 & 85 & 23 & CAM & & & $51 \%$ & & & \\
\hline McAvay 2006 & M & 55 & 80 & 27 & CAM & $24 \%$ & & & & & \\
\hline Inouye 2007 & $M$ & 169 & 80 & 20 & CAM & $51 \%$ & & & & & \\
\hline Lundstrom 2007 & $S$ & 129 & 82 & 32 & DSM4 & $12 \%$ & & & & & \\
\hline Kiely et al. 2009 & PAC & 412 & 84 & 38 & CAM & & $67 \%$ & $56 \%$ & $40 \%$ & $32 \%$ & \\
\hline McManus 2009 & Stroke & 23 & 75 & & CAM & & & $64 \%$ & & & \\
\hline Arinzon 2011 & $\mathrm{M}$ & 92 & 80 & 90 & CAM, DRS & & $50 \%$ & & & & \\
\hline Lee 2011 & $S$ & 70 & 80 & 10 & CAM & & & $20 \%$ & & $3 \%$ & $3 \%$ \\
\hline Witlox 2013 & $S$ & 27 & 84 & & CAM & & & & $19 \%$ & & \\
\hline Velilla 2013 & M & 45 & 87 & & CAM, DSM-IV & & & $18 \%$ & & & \\
\hline $\begin{array}{l}\text { Cole } 2015 \\
\text { Vasunilashorn }\end{array}$ & $M, S$ & 278 & 85 & 55 & CAM & & & $73 \%$ & $61 \%$ & & \\
\hline 2016 & M, S & 250 & 79 & & CAM & $24 \%$ & & & & & \\
\hline Miu 2016 & PAC & 89 & 84 & & CAM & $79 \%$ & & $85 \%$ & $55 \%$ & & \\
\hline Jackson 2016 & M & 125 & 84 & 36 & DSM-IV & & & & $6 \%$ & & \\
\hline Cole 2017 & $\mathrm{M}, \mathrm{S}$ & 152 & 85 & 52 & CAM & & & $63 \%$ & & & \\
\hline Reznik 2021 & Stroke & 590 & 71 & 13 & DSM-5 & $48 \%$ & & & & & \\
\hline
\end{tabular}


medRxiv preprint doi: https://doi.org/10.1101/2022.01.20.22269044; this version posted January 21, 2022. The copyright holder for this preprint (which was not certified by peer review) is the author/funder, who has granted medRxiv a license to display the preprint in perpetuity.

It is made available under a CC-BY 4.0 International license.

Table 2. Meta-regression estimating the proportion of individuals with persistent delirium

\begin{tabular}{|c|c|c|c|c|c|c|c|c|}
\hline \multirow[b]{3}{*}{ Time (weeks) $(n=37)$} & \multicolumn{4}{|c|}{ Univariable } & \multicolumn{4}{|c|}{ Multivariable } \\
\hline & \multirow{2}{*}{$\frac{\beta}{-0.7}$} & \multicolumn{2}{|c|}{$95 \% \mathrm{Cl}$} & \multirow{2}{*}{$\frac{\mathbf{p}}{0.02}$} & \multirow{2}{*}{$\frac{\beta}{-0.6}$} & \multicolumn{2}{|c|}{$95 \% \mathrm{Cl}$} & \multirow{2}{*}{$\frac{p}{0.02}$} \\
\hline & & -1.2 & -0.1 & & & -1.2 & -0.1 & \\
\hline Age (per SD) $(\mathrm{n}=37)$ & 9.1 & 0.9 & 17.4 & 0.03 & 8.8 & 1.1 & 16.5 & 0.03 \\
\hline Dementia \% (n=24) & 0.3 & -0.1 & 0.8 & 0.14 & & & & \\
\hline
\end{tabular}


medRxiv preprint doi: https://doi.org/10.1101/2022.01.20.22269044; this version posted January 21, 2022. The copyright holder for this preprint (which was not certified by peer review) is the author/funder, who has granted medRxiv a license to display the preprint in perpetuity.

It is made available under a CC-BY 4.0 International license.

Figure 1. PRISMA flow detailing study selection process.

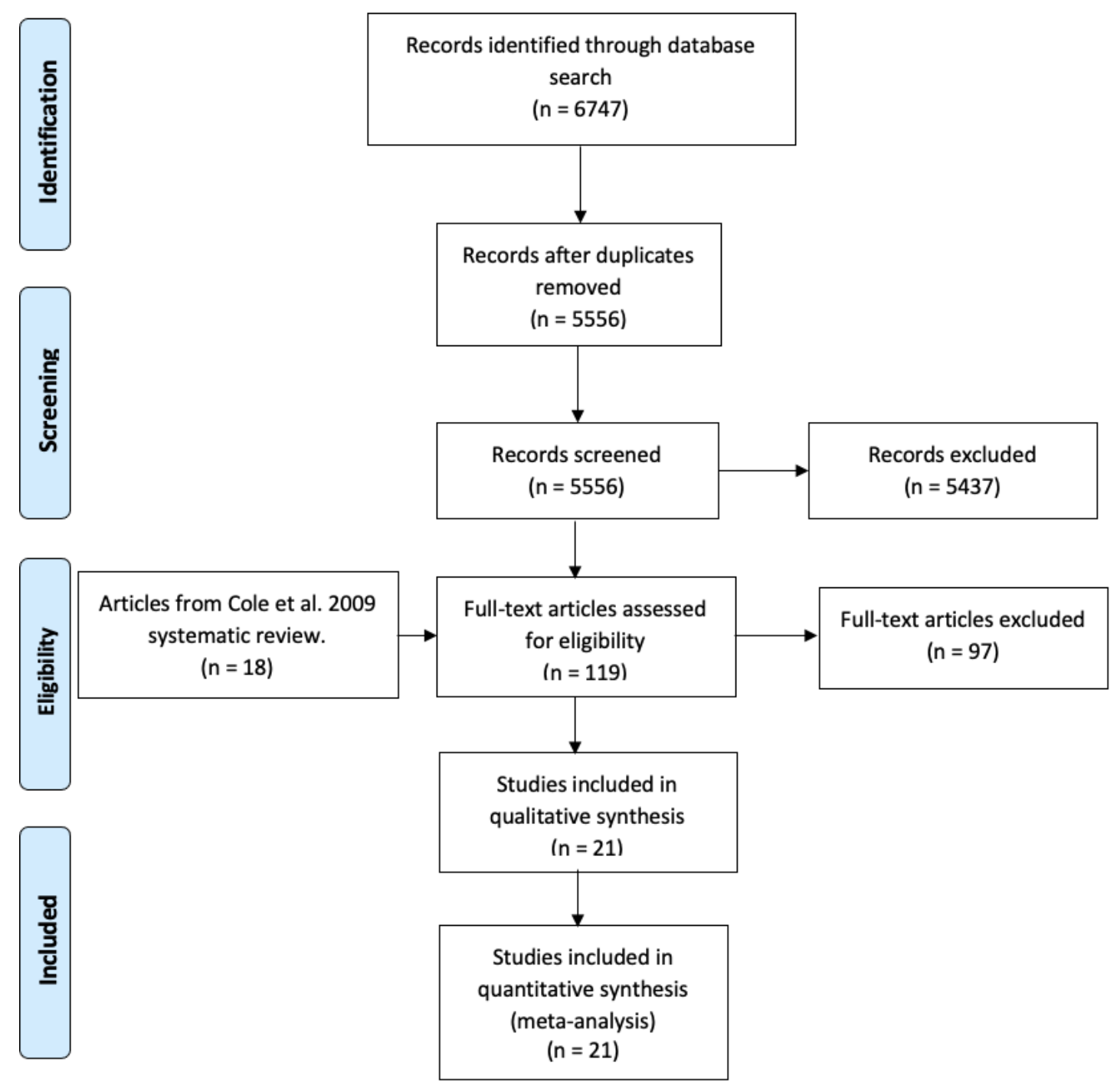


medRxiv preprint doi: https://doi.org/10.1101/2022.01.20.22269044; this version posted January 21, 2022. The copyright holder for this preprint (which was not certified by peer review) is the author/funder, who has granted medRxiv a license to display the preprint in perpetuity.

It is made available under a CC-BY 4.0 International license.

Figure 2. Assessment of risk of bias.

\begin{tabular}{|c|c|c|c|c|c|c|}
\hline & \multicolumn{6}{|c|}{ Risk of bias domains } \\
\hline & D1 & D2 & D3 & D4 & D5 & Overall \\
\hline Levkoff 1992 & (+) & (†) & & (t) & & (†) \\
\hline Rudberg 1997 & & & & + & & \\
\hline Marcantonio 200 & (+) & (t) & & (†) & & $\Rightarrow$ \\
\hline Kelly 2001 & & & & & & \\
\hline McCusker 2003 & (†) & ( & & + & & \\
\hline Kiely 2004 & & & & + & & $\Rightarrow$ \\
\hline McAvay 2006 & & & & & + & \\
\hline Inouye 2007 & & & & & & \\
\hline Lundstrom 200 & & & & & \pm & \\
\hline Kiely 2009 & & & & & & \\
\hline McManus 2009 & & & & & & \\
\hline Arinzon 2011 & & & & & +) & \\
\hline Lee 2011 & & & & & & \\
\hline Witlox 2013 & & (t) & & & (t) & \\
\hline Velilla 2013 & & (†) & & & & \\
\hline Cole 2015 & & (+) & & & (†) & \\
\hline Vasunilashorn 20 & & (t) & & & (+) & \\
\hline Miu 2016 & & + & & & \pm & \\
\hline Jackson 2016 & (t) & (+) & & + & + & (t) \\
\hline Cole 2017 & (+) & + & & $\oplus$ & (†) & (t) \\
\hline Reznik 2021 & & (+) & (+) & & + & \\
\hline
\end{tabular}

D1: Bias arising from specific patient settings

D2: Bias arising from sample selection

D3: Bias arising from sampling criteria

D4: Bias arising from reference standard used

D5: Bias from expertise in applying reference standard
Judgement

(†) Low

- Some concerns 
medRxiv preprint doi: https://doi.org/10.1101/2022.01.20.22269044; this version posted January 21, 2022. The copyright holder for this preprint (which was not certified by peer review) is the author/funder, who has granted medRxiv a license to display the preprint in perpetuity.

It is made available under a CC-BY 4.0 International license .

Figure 3. Forest plot showing pooled estimates of persistent delirium over time.

Study

Discharge

Inouye 2007

Kelly 2001

Levkoff 1992

Lundstrom 2007

Marcantonio 2000

McAvay 2006

McCusker 2003

Miu 2016

Reznik 2021

Rudberg 1997

Vasunilashorn 2016

Subgroup $(\mathrm{I}$-squared $=97.1 \%)$

2 weeks

Arinzon 2011

Kiely et al. 2009

Subgroup (l-squared $=88.7 \%$ )

1 month

Cole 2015

Cole 2017

Kelly 2001

Kiely 2004

Kiely et al. 2009

Lee 2011

Marcantonio 2000

McManus 2009

Miu 2016

Velilla 2013

Subgroup (l-squared $=96.0 \%)$

\section{3 months}

Cole 2015

Jackson 2016

Kelly 2001

Kiely et al. 2009

Levkoff 1992

Miu 2016

Witlox 2013

Subgroup $(\mathrm{l}$-squared $=97.9 \%)$

\section{6 months}

Kiely et al. 2009

Lee 2011

Levkoff 1992

Marcantonio 2000

McCusker 2003

Subgroup (l-squared $=96.9 \%$ )

\section{2 months}

Lee 2011

McCusker 2003

Subgroup (l-squared $=98.8 \%$ )
Effect $(95 \% \mathrm{Cl})$ Weight
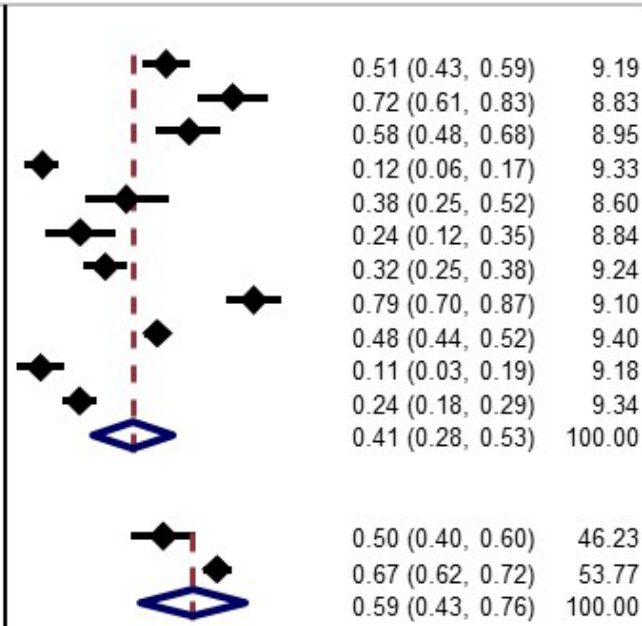

$0.50(0.40,0.60) \quad 46.23$

$0.67(0.62,0.72) \quad 53.77$

$0.59(0.43,0.76) \quad 100.00$

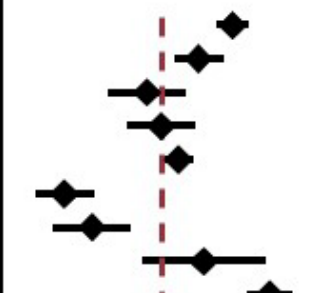

$0.73(0.68,0.78) \quad 10.52$

$0.63(0.55,0.70) \quad 10.32$

$0.46(0.33,0.59) \quad 9.76$

$0.51(0.40,0.61) \quad 10.00$

$0.56(0.51,0.61) \quad 10.54$

$0.20(0.11,0.29) \quad 10.15$

$0.29(0.16,0.41) \quad 9.78$

$0.64(0.44,0.84) \quad 8.65$

$0.85(0.78,0.92) \quad 10.34$

$0.18(0.07,0.29) \quad 9.93$

$0.51(0.37,0.64) \quad 100.00$

$0.61(0.55,0.67) \quad 14.63$

$0.06(0.02,0.10) \quad 14.73$

$0.25(0.14,0.36) \quad 14.09$

$0.40(0.35,0.45) \quad 14.70$

$0.37(0.27,0.47) \quad 14.21$

$0.55(0.45,0.65) \quad 14.16$

$0.19(0.04,0.34) \quad 13.50$

$0.35(0.17,0.53) \quad 100.00$

$0.32(0.27,0.37) \quad 20.42$

$0.03(-0.01,0.07) \quad 20.52$

$0.31(0.21,0.41) \quad 19.11$

$0.06(-0.01,0.12) \quad 20.03$

$0.31(0.25,0.38) \quad 19.92$

$0.20(0.06,0.35) \quad 100.00$

$0.03(-0.01,0.07) \quad 50.32$

$0.41(0.34,0.48) \quad 49.68$

$0.22(-0.16,0.59) \quad 100.00$ 
medRxiv preprint doi: https://doi.org/10.1101/2022.01.20.22269044; this version posted January 21, 2022. The copyright holder for this preprint (which was not certified by peer review) is the author/funder, who has granted medRxiv a license to display the preprint in perpetuity.

It is made available under a CC-BY 4.0 International license.

Figure 4. Meta-regression showing estimated prevalence over time, with marginal predictions stratified by age.

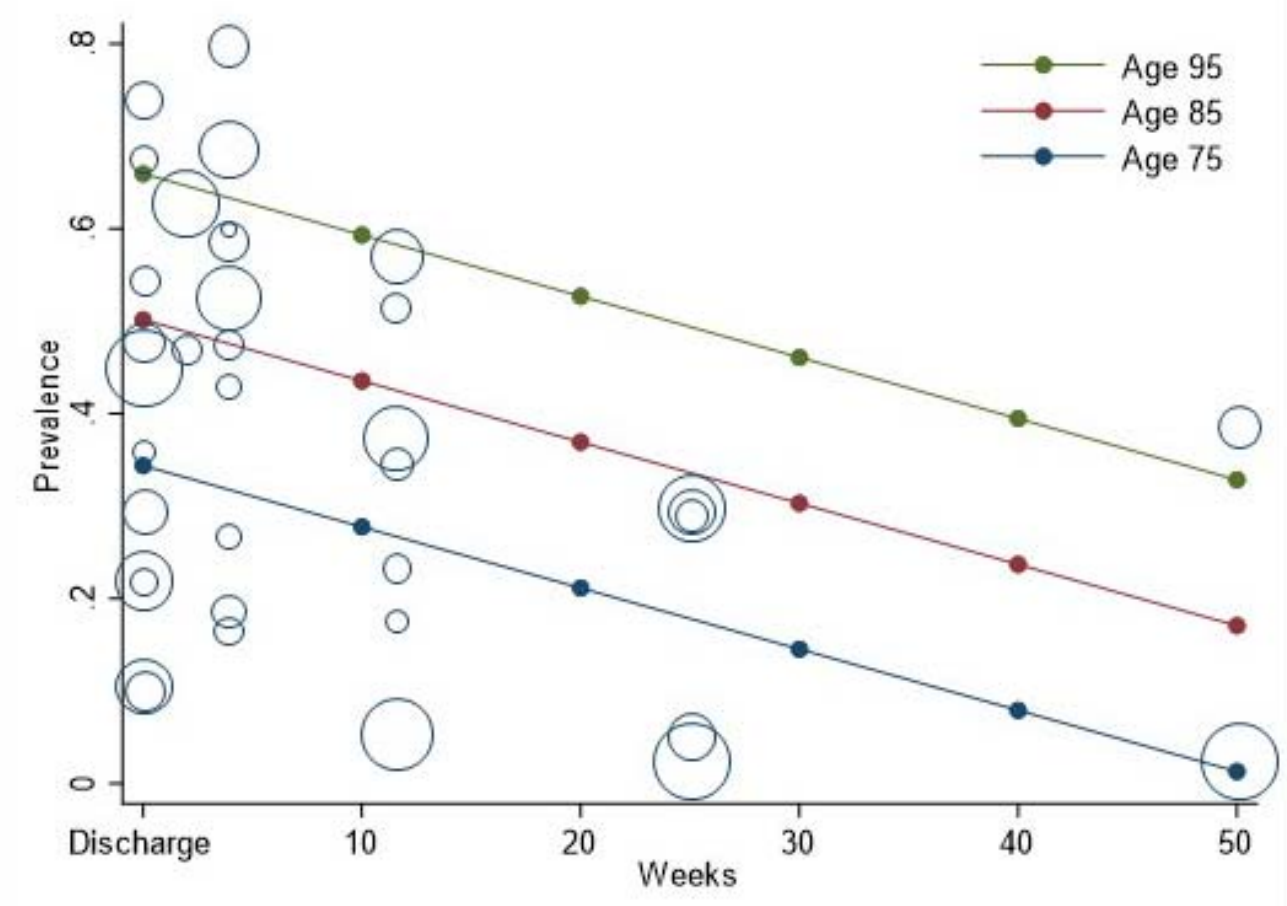

